\title{
マグネシウム合金の射出成形技術に関する基礎研究*
}

（第 2 報，マグネシウム合金粒子充填層の有効熱伝導率）

\author{
尾 崎公一*1, 近藤 秀 樹*2, 中 村 俊 介*3

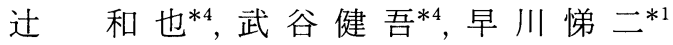

\section{Fundamental Study on Injection Molding of Magnesium Alloy \\ (2nd Report, Effective Thermal Conductivity of Packed Bed of Magnesium Alloy Particles)} \\ Koichi OZAKI ${ }^{* 5}$, Hideki KONDO, Shunsuke NAKAMURA, \\ Kazuya TSUJI, Kengo TAKEYA and Teiji HAYAKAWA \\ ${ }^{* 5}$ Department of System Engineering, Okayama Prefectural University, \\ 111 Kuboki, Soja-shi, Okayama, 719-1197 Japan

\begin{abstract}
The present study investigated experimentally the effects of temperature and pressure upon effective thermal conductivity of packed bed of magnesium alloy particles. The test particles made of AM50A or AZ91D were poured into a cylindrical vessel and were applied a given superficial pressure for six hours under a constant temperature condition. The superficial pressure was changed between $2.5 \mathrm{MPa}$ and $10 \mathrm{MPa}$, and the temperature was varied from $95.5^{\circ} \mathrm{C}$ to $457^{\circ} \mathrm{C}$. After removing the packed bed of magnesium alloy particles from the cylindrical vessel, the measurement of effective thermal conductivity was carried out under the steady state comparison method. The effective thermal conductivity increased with an increasing in the pressure, temperature and the thermal conductivity of the particle. At a given material of particle, the effective thermal conductivity was mainly dominated by the relative density and was increased with an increasing in the relative density. The dependency of the effective thermal conductivity upon the relative dencity was remarkable in the low relative dencity region and the high relative dencity region.
\end{abstract}

Key Words: Molding Methods, Nonferrous Metal, Material Testing, Packed Bed, Thermophysical Property, Magnesium Alloy, Injection Molding

\section{1. 緒 言}

近年, 大気中の $\mathrm{CO}_{2}$ 濃度の上昇など環境問題が深 刻化している.このような背景のもと, 軽量で省エネ ルギーに役立ち,かつリサイクル性の高い素材として, マグネシウム合金 (以下, $\mathrm{Mg}$ 合金と略) が注目されて いる.

$\mathrm{Mg}$ 合金成形法の一つである射出成形法 (チクソモー ルド法) は, 防然ガスが不要かつ成形品の機械的性質 に優れ,さらに半溶融成形のため溶解に必要なエネル ギーが少ないなど,多数の特徵を有している.しかし射 出成形機内部における $\mathrm{Mg}$ 合金粒子群の輸送·融解現 象は, 高温高圧のため実測が困難なことから, 定量的に 解明されておらず, 数值解析による予測技術の構筑が

* 原稿受付 2005 年 9 月 26 日.

*1 正員, 岡山県立大学情報工学部(西719-1197 総社市洼木 111).

*2 岡山県立大学大学院情報系工学研究科 [現：アイシンエイ ダブリュ (株)].

*3 岡山県立大学大学院情報系工学研究科.

*4 (株) 日本製鋼所 (亚736-860) 㕕岛市安芸区船越南 1-6-1).

E-mail : ozaki a cse.oka pu.ac.jp
望まれている.このためには, まず, $\mathrm{Mg}$ 合金粒子群の 見掛け物性值の定量的評価が必要である.

粒子群の見掛け物性值の多くは, 粒子の物性値と粒 子間に存在する流体の物性值, そして粒子の質量分率 から推算できる.(1) このことから, 著者らは $\mathrm{Mg}$ 合金粒 子群のかさ密度に与える温度 ·圧力・時間の影響を実 験的に検討し, (2) かさ密度の増加速度を温度, 圧力, か さ密度の関数として実験整理式にまとめた. 一方, 粒 子群の有効熱伝導率の推算法については, 従来から多 数検討されているが, (1),(3),(4) 粒子が孤立している, も しくは粒子同士が点接触状態にある系を対象とした研 究が多く,射出成形機内部の $\mathrm{Mg}$ 合金粒子群のように, 加熱·圧縮により粒子が変形し,さらに充填率が 0.45 程度から 1 近くにまで変化する系を系統的に扱った研 究は, 著者らの知る限りにおいては存在しない.

本報では, 種々の温度·圧力条件下で作製された $\mathrm{Mg}$ 合金粒子充填層を対象に, その有効熱伝導率を定常比 較法により測定し,これに与える温度, 圧力の影響につ 
いて検討すると共に, 数値解析に有用なよう, 得られた 結果を実験整理式にまとめる.

\section{2. $\mathrm{Mg}$ 合金粒子の諸特性と $\mathrm{Mg}$ 合金粒子充填層の作 製法}

$2.1 \mathrm{Mg}$ 合金粒子の諸特性本報では, 前報(2) と 同様, AM50A と AZ91D の 2 種類の Mg 合金試料 ((株) 日本製鋼所製，公称寸法 $2.2 \mathrm{~mm}$ ) を用いた. 以下にそ の概要を述べる.

常温における物理特性の概略 (5),(6) を表 1 に示す。 AM50A と AZ91D を比較すると, 降伏応力 $\sigma_{y}$ は AZ91D の方が約 $28 \%$ 高く, 伸びは AM50A の方が 約 3 倍大きい. また, 熱伝導率は, AM50A の方が約 27 \%大きい.

本供試 $\mathrm{Mg}$ 合金粒子は, 結晶粒径約 $200 \mu \mathrm{m}$ のイン ゴットから削り出されたもので, 図 1 (a), (b) に示すよ うに，その形状は概数直方体である. AM50A 粒子お よび AZ91D 粒子の平均寸法は, それぞれ $2.51 \mathrm{~mm} \times$ $1.36 \mathrm{~mm} \times 0.877 \mathrm{~mm}$ および $2.46 \mathrm{~mm} \times 1.60 \mathrm{~mm} \times$ $1.00 \mathrm{~mm}$ である.

$2 \cdot 2 \mathrm{Mg}$ 合金粒子充填層の作製法 $\mathrm{Mg}$ 合金粒子 充填層は, 前報(2) の加熱圧縮実験装置で作製した. 以 下, その方法を簡単に述べる. 図 2 に示されるように, SUS310S 製の圧縮試験容器は, シリンダ (内径 $50 \mathrm{~mm}$ $\times$ 高さ $100 \mathrm{~mm}$ ), ピストン (外径 $49.5 \mathrm{~mm} \times$ 高さ 95 $\mathrm{mm}$ ) および底板 (外径 $49.5 \mathrm{~mm} \times$ 厚さ $10 \mathrm{~mm}$ ) からな り,これらに囲まれる空間には, $\mathrm{Mg}$ 合金粒子約 $32 \mathrm{~g}$ が

Table 1 Physical properties.

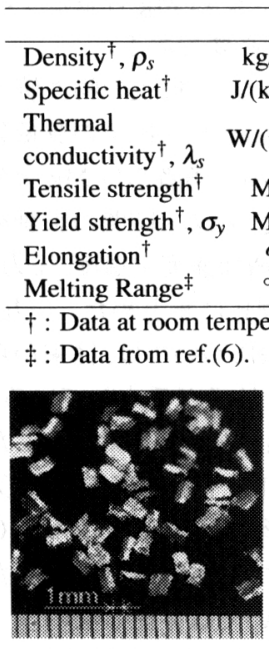

(a) AM50A

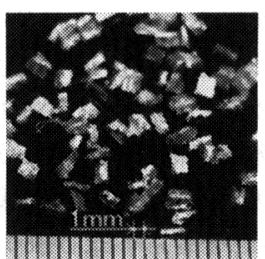

(b) AZ91D
Fig. 1 Photo of test particles.
充填される. 圧縮試験容器は, 加熱炉を装備した引っ張 り試験器の圧縮治具に設置され, 一定の温度 · 荷重状 態で 6 時間圧縮される. 試料温度 $T$ は, 圧縮容器底板 の上面から $3 \mathrm{~mm}$ 下方に取り付けた $\mathrm{K}$ 型シース熱電 対 (直径 $1.0 \mathrm{~mm}$ ) で測定した. 荷重 $F$ は, 引張試験機の ロードセルで測定した. 除荷後に $\mathrm{Mg}$ 合金粒子群を圧 縮試験容器から取り出し, その直径 $D$ と厚さ $h$ をノギ スで, 質量 $m$ を電子天秤 (最小目盛 $1 \mathrm{mg}$ ) で計測し, か さ密度 $\rho_{a e}$ を次式により算出した。

$$
\rho_{a e}=4 m /\left(\pi D^{2} h\right)
$$

$M g$ 合金粒子充填層の充填率 $\phi$ は次式で求めた.

$$
\phi=\rho_{a e} / \rho_{s}
$$

ここに, $\rho_{s}$ は $\mathrm{Mg}$ 合金粒子の密度である.また見掛け 圧力 $P_{a}$ は, 荷重 $F$ と直径 $D$ により, 次のように定義 した.

$$
P_{a}=4 F /\left(\pi D^{2}\right)
$$

各測定器の精度を用いて誤差解析を行った結果, $T$ の 精度は土6 K 以内, $P_{a}$ は土 $1.2 \%$ 以内, $\rho_{a e}$ と $\phi$ は土 $0.2 \%$ 以内と推定される.

上記の手順で作製された $\mathrm{Mg}$ 合金粒子充填層の外観 の一例を, 図 3 に示寸. 同図に示されるように, Mg 合

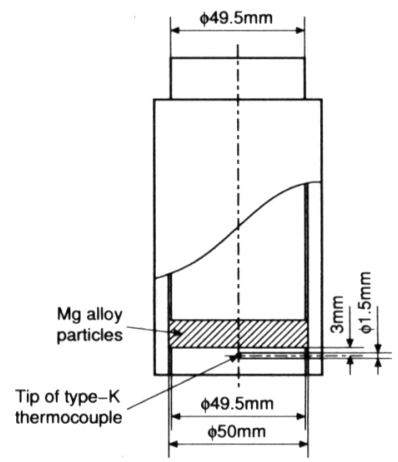

Fig. 2 Detail of compression test vessel.

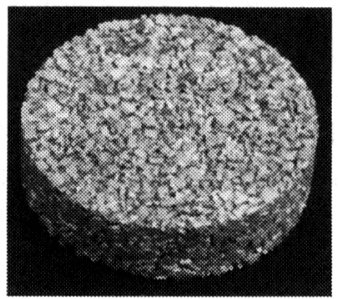

Fig. 3 Photo of packed bed of AM50A particles compressed at condition of $7.5 \mathrm{MPa}$ and $200^{\circ} \mathrm{C}$. 
金粒子充填層は円柱状の多孔質体である. 厚さ $h$ は条 件により異なるが, 未圧縮時には約 $20 \mathrm{~mm}$, 固体に近 い高充填率では約 $9 \mathrm{~mm}$ である.

圧縮条件の概略と $\mathrm{Mg}$ 合金粒子充填層の充填率の範 囲を以下に示す。

粒子材質 : AM50A, AZ91D

荷重 $F=500 \mathrm{kgf} \sim 2000 \mathrm{kgf}$

(見掛け圧力 $P_{a}=2.5 \mathrm{MPa} \sim 10 \mathrm{MPa}$ )

時間平均温度 $T_{m}=95.5{ }^{\circ} \mathrm{C} \sim 4577^{\circ} \mathrm{C}$

$\mathrm{Mg}$ 合金粒子充填層の充填率 $\phi=0.482 \sim 0.983$ なお, 本実験条件の最低荷重である $F=500 \mathrm{kgf}$ の場合, AM50A では $200{ }^{\circ} \mathrm{C}$ 以下, AZ91D では $150^{\circ} \mathrm{C}$ 以下の 条件において, 圧縮容器から取り出寸際に $\mathrm{Mg}$ 合金粒 子充填層が崩壊したので,これらの条件に関しては有 効熱伝導率は測定出来なかった.

\section{3. 有効熱伝導率測定装置およひ測定法}

図 3 に示したように, $\mathrm{Mg}$ 合金粒子充填層は多孔質 体であるため, 本研究では熱容量等の影響を補正する 必要がない定常比較法を採用した.

有効熱伝導率測定装置の概略を図 4 に示す. 有効熱 伝導率測定装置は, $\mathrm{Mg}$ 合金粒子充填層の有効熱伝導率 測定に用いる試験部, 試験部への冷熱供給のための恒温 水槽 (EYELA 製 NCB-3100, 温度制御精度 $\pm 0.01{ }^{\circ} \mathrm{C}$ ), 試験部に内蔵された加熱ヒータの制御機器 (CHINO 製 温調器 DB1000 とサイリスタレギュレータ), デジタル マルチメータ (アドバンテスト製 R6871EDC, 分解能 $0.1 \mu \mathrm{V})$, デジタルマルチメータに接続するセンサを切 り替えるためのスキャナ (アドバンテスト製 R7210), そしてデータ収録のためのパーソナルコンピュータか ら構成されている.

試験部の詳細を図 5 に示す. 加熱部は, 直径 $50 \mathrm{~mm}$ $\times$ 高さ $50 \mathrm{~mm}$ の銅製ブロックに電気ヒータ (八光電熱

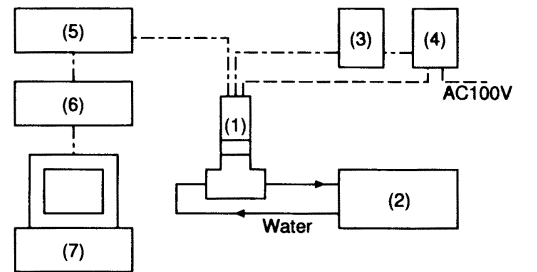

$\begin{array}{llll}1 & \text { Test section } & 2 & \text { Const. temp. bath } \\ 3 & \text { Temp. controller } & 4 & \text { Thyristor regulator } \\ 5 & \text { Scanner } & 6 & \text { Digital multi mater } \\ 7 & \text { Personal computer } & & \end{array}$

Fig. 4 Schematic diagram of effective thermal conductivity measurement device.
器製 HLK1 102, 直径 $6.25 \mathrm{~mm} \times$ 長さ $25.4 \mathrm{~mm}$, 最大出 力 $150 \mathrm{~W}$ ) を 7 個取り付けたものである (取付位置は A-A 断面図参照). これら 7 個のヒータは並列に接続 されており, ヒータへの電気入力は, 加熱部中央のヒー タ表面温度が $50{ }^{\circ} \mathrm{C}$ になるよう, 温調器とサイリスタ レギュレータにより調整される. 加熱部の底面にはエ ポキシ樹脂を介して厚さ $2 \mathrm{~mm}$ の銅製伝熱面が取り付 けられており, その裹面 (ヒータを取り付けた銅製ブ ロック側) には, B-B 断面図に示す 6 箇所に $\mathrm{T}$ 型熱電 対 (素線直径 $0.1 \mathrm{~mm}$ ) が取り付けられている. 加熱面 温度 $T_{h}$ は, 銅製伝熱面の中央, および中央から $10 \mathrm{~mm}$ の位置に取り付けた合計 5 個の熱電対の算術平均温度 とした.

試料下部には銅製ブロックからなる冷却部が取り付 けられており, 恒温槽から $15^{\circ} \mathrm{C}$ 一定温度の冷却水が 循環されている. 冷却部の上部には厚さ $2 \mathrm{~mm}$ の銅製 伝熱面が取り付けられており, その裏面には加熱面と 同様な配置で, $\mathrm{T}$ 型熱電対 (素線直径 $0.1 \mathrm{~mm}$ ) が取り 付けられている. 冷却面温度 $T_{c}$ は, 加熱面温度と同様 に, 中央部の 5 個の熱電対の算術平均温度とした. な お, 加熱面, 冷却面共に, 各伝熱面に取り付けた 6 個の 熱電対の指示温度は $\pm 0.2 \mathrm{~K}$ 以内であった.

銅製ブロックと伝熱面との間には極薄型の熱流束計 $(10 \mathrm{~mm} \times 10 \mathrm{~mm} \times 0.4 \mathrm{~mm})$ が取り付けられており,こ れにより試料から冷却部への伝熱量を測定した. なお 銅製ブロック, 伝熱面および熱流束計の接合部にはエ ポキシ樹脂を充填し,密着を図った.

加熱部, 冷却部および $\mathrm{Mg}$ 合金充填層を覆うように

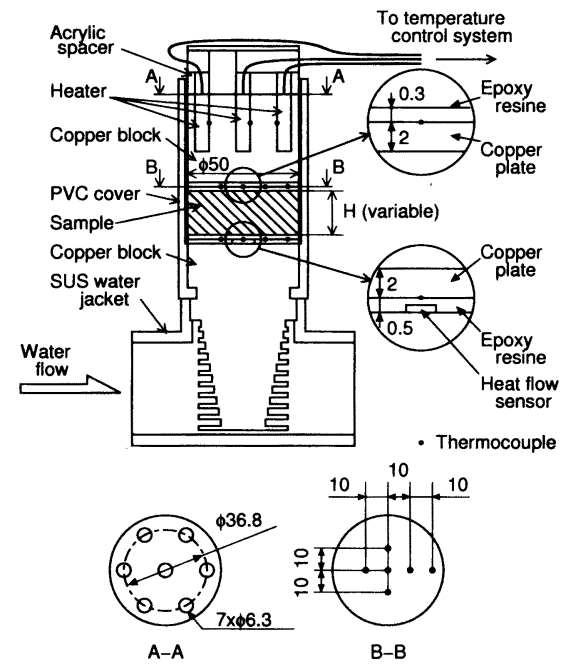

Fig. 5 Detail of test section 
塩化ビニル製カバー (内径 $D=53.5 \mathrm{~mm}$, 肉厚 $1 \mathrm{~mm}$ ) を取り付け,その周囲にグラスウール断熱材を巻き付 けた.

接触熱抵抗を極力减ずるため, 加熱面と冷却面の表 面を研磨仕上げし, $\mathrm{Mg}$ 合金粒子充填層の上下面も面出 しを行った.さらに接触部に空気層が形成されないよ う, 加熱面と冷却面の表面にシリコンオイルスプレー を吹き付けた.

$\mathrm{Mg}$ 合金粒子充填層の有効熱伝導率測定に先立ち, パ イレックスガラス, SUS304, S35C, AZ31, AZ91D の円 盤状試料 (直径 $50 \mathrm{~mm}$, 厚さ $5,7,10,20 \mathrm{~mm}$ ) を用い, キャリブレーションを行った. その結果を図 6 に示す. なお, 各試料の熱伝導率は文献(5),(7)-(10) によった. 同 図に示されるように, 本装置による測定値 $\lambda_{e}$ は, 文献 值 $\lambda_{s}$ に良く一致している. 特に, 試料厚さが $10 \mathrm{~mm}$ 以 上の場合の精度は $\pm 15 \%$ 以内であり, 前述したように 本 $\mathrm{Mg}$ 合金粒子充填層が $9 \mathrm{~mm}$ 以上の厚さであること を考虑すると, 本装置の精度は十分と考えられる.

\section{4. 測定結果及び考察}

4.1 粒子同士の接触状態 $\mathrm{Mg}$ 合金粒子充填層 の断面をエッチング後にデジタルカメラで撮影し, 画 像解析を行った. $\mathrm{Mg}$ 合金部を白色, 空隙部を黒色に 2 值化処理後, 粒子同士の接触部の画素を赤く着色した. 図 7 は, AZ91 粒子を用いた場合の画像処理結果例を 示す. 充填率が低い図 7 (a) では, 平均的に見ると粒子 同士の接触部は小さいが, 一部の粒子については周り の粒子と大きな接触面積を有している. これは, 充填率 が低い場合, 荷重は一部の粒子で負担されているため と考えられる. 一方, 充填率が高い図 7 (b) では, 各粒 子は周囲の粒子と大きな接触面積を有しており, 粒子

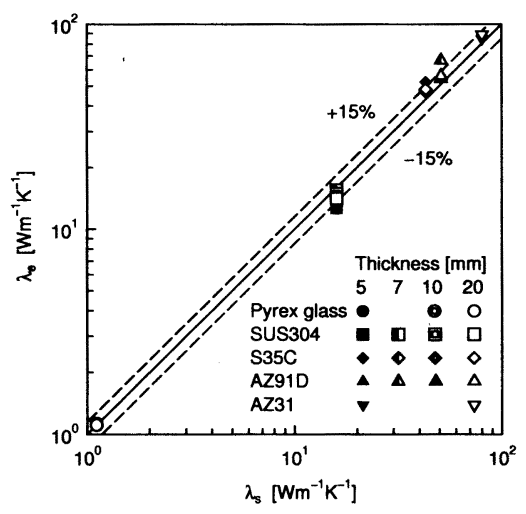

Fig. 6 Result of calibration of thermal conductivity measurement device.
ごとのばらつきも小さくなっている.

断面画像における各粒子について周長 $L_{p}$ と接触部 の長さ $L_{c}$ を求め, これらの総和 $\sum L_{p}, \Sigma L_{c}$ が断面位置 に依存しないと仮定し, $\sum L_{c} / \sum L_{p}$ をもって粒子表面積 に対する接触部面積の割合を評価した. $\sum L_{c} / \sum L_{p}$ と 充填率 $\phi$ の関係を示したのが図 8 である. 図 8 中に は, 球状粒子充填層における粒子の接触面積に関する Fischmeister-Arzt の解(11) を比較のために実線で併記 してある. なお Fischmeister-Arzt の解では, もとの球 状粒子の表面積 $\left(4 \pi R^{2}\right)$ に基づいて接触部の面積 $a$ が 無次元化されている.

図 8 において, 未圧縮状態の $\mathrm{Mg}$ 合金粒子群を樹脂 に包埋して得た $\sum L_{c} / \sum L_{p}$ が, 接触点に荷重が作用し ていないにも拘わらず約 0.13 と比較的大きな值をとっ ていることから, $\Sigma L_{c} / \sum L_{p}$ の值は, 真実接触面積の割 合ではなく, 見掛け接触面積の割合を表していること

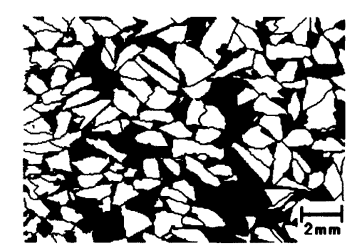

(a) $P_{a}=10 \mathrm{MPa}, T_{m}=150^{\circ} \mathrm{C}$

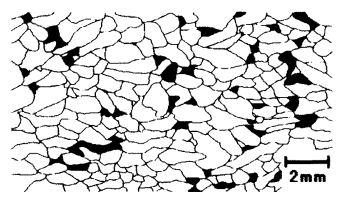

(b) $P_{a}=2.5 \mathrm{MPa}, T_{m}=450^{\circ} \mathrm{C}$

Fig. 7 Results of image processing for packed bed of AZ91D particles.

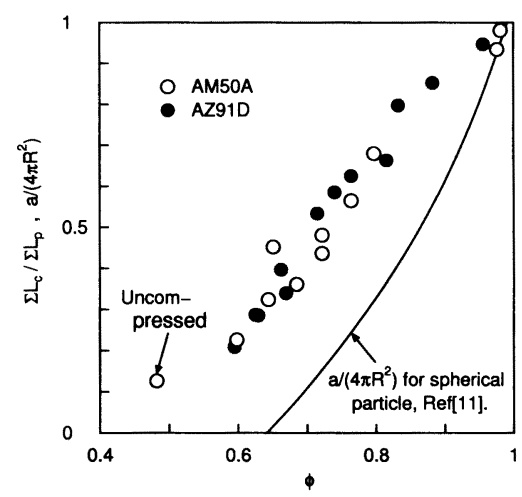

Fig. 8 Variation of contact length ratio with relative density. 
が理解できる. $\phi$ へ依存性について観察すると, 球状 粒子に関する実線では, $\phi$ の増加に伴い接触面積の増 加割合が単調に増加するのに対し, 直方体状粒子に関 する本 $\sum L_{c} / \sum L_{p}$ 值では, $\phi<0.6$ では変化が小さく, $0.6<\phi<0.85$ で $\phi$ と共に直線的に増大し, $\phi>0.85$ で再び増加割合を減じる傾向にある.このように球状 粒子と直方体状粒子で傾向が異なるのは, 球状粒子の 場合には, 充填率の増大に際して接触部の変形を伴う が, 直方体状粒子の場合には, 接触部の変形のみなら ず, 粒子の配置も大きく変化するためと考えられる.ま た, $\phi$ の值を固定した場合には, 直方体状粒子に関する 本 $\sum L_{c} / \sum L_{p}$ 值は, 球状粒子に関する実線に比べて大 きくなっている. 一方, $\sum L_{c} / \sum L_{p}$ 值に及ぼす粒子材質 の影響について AM50A と AZ91D の結果を比較する と,両者には大きな差は見られないものとなった.

4.2 有効熱伝学率の見掛け圧力および温度への依 存性図 9 は, $\mathrm{Mg}$ 合金粒子充填層の有効熱伝導率 $\lambda_{e}$ と $\mathrm{Mg}$ 合金粒子充填層作製時の温度 $T_{m}$ との関係を,

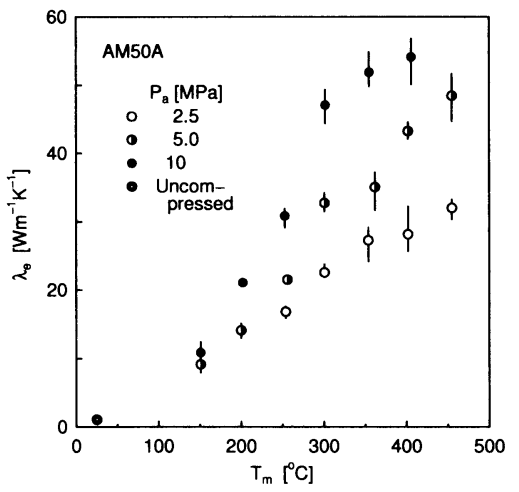

(a) AM50A

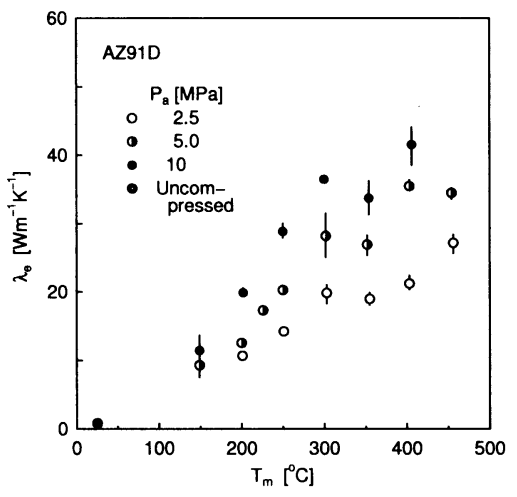

(b) AZ91D

Fig. 9 Variation of effective thermal conductivity with temperature for various superficial pressure.
種々の見掛け圧力 $P_{a}$ について示したものである. 同図 中の実線は, 3 回の測定值の最大值と最小值を結んだ ものであり, 記号は平均値を示している. また同図中に は, 未圧縮状態の $\mathrm{Mg}$ 合金粒子群の有効熱伝導率の測 定値も併記してある. AM50A に関する図 9 (a) におい て, いずれの $P_{a}$ に関しても $\lambda_{e}$ は $T_{m}$ の増加に伴い大 きくなっている. また, $T_{m}$ を固定した場合には, $\lambda_{e}$ は $P_{a}$ と共に大きくなっている.これは, かさ密度に関す る前報(2) で明らかにしたように, $T_{m}$ や $P_{a}$ の増加に伴 い充填率が高くなることや, 図 8 で述べたように, 充填 率の増加に伴い $\mathrm{Mg}$ 合金粒子同士の接触面積が増加す るためと考えられる.

AZ91D に関する図 9 (b) においても, 定性的には図 9 (a) と同様な傾向が観察されるが, $T_{m}$ と $P_{a}$ を一定と した場合の $\lambda_{e}$ は, AZ91Dの方が小さくなっている.こ れは, AZ91D の方が粒子自体の熱伝導率が小さいため と考えられる. なお, 図 9 (b) において, $T_{m}$ が $300^{\circ} \mathrm{C}$ か ら $350^{\circ} \mathrm{C}$ 一と増加する際, $\lambda_{e}$ が若干小さくなっている が,これは, 本実験では高温で圧縮した $\mathrm{Mg}$ 合金粒子充 填層を常温に椧却してから有効熱伝導率を測定してい るため, 延性に乏しいAZ91Dでは, 冷却時の熱収縮に より粒子同士の接触部にわずかな間隙が生じたためと 考えられる.

4.3 有效熱伝導率のかさ密度への依存性と無次元 整理球状粒子充填層の有効熱伝導率に関する従来 の研究(3),(4) においては, 有効熱伝導率は分散相 (固相) と連続相 (空気) の熱伝導率, そして充填率の関数とし て表現されている.これらを参考にして, 図 9 のデータ を $\lambda_{e} / \lambda_{s}$ 対 $\phi$ の座標上に再プロットしたものが図 10 である.なお本 $\mathrm{Mg}$ 合金粒子の熱伝導率は, インゴット からの切削時に導入された欠陥や, その後の加熱 ·圧 縮実験において生じる回復·再結晶や塑性変形の影響 を受けるが, 実験毎に Mg 合金粒子の熱伝導率を評価 するのは困難なため, データ整理にはバルク材の熱伝 導率 $\lambda_{s}$ を用いてある. 同図中には, 球状粒子充填層に 関する Maxwell の式(3) と Bruggeman の式(4) を, それ ぞれ一点鎖線および破線で併記してある.いずれの式 に関しても, Mg 合金を連続相, 空気を分散相と考えた 場合と, 空気を連続相, Mg 合金を分散相と考えた場合 の双方を記入している.

まず, AM50A に関する図 10 (a) について観察する . と, $\lambda_{e} / \lambda_{s}$ の実験值は, 未圧縮状態では $\mathrm{Mg}$ 合金粒子を 分散相と考えた場合の従来の式による予測値に近い值 を示すが, $\phi$ の増加に伴い急激にこれらの予測值よりも 大きくなる.これは,粒子同士が接合し, 固体を通じる 熱流経路が形成されるためと考えられる.しかし, $\mathrm{Mg}$ 
合金を連続相と考えた場合の予測值に比べると, $\lambda_{e} / \lambda_{s}$ の実験值は小さい値となっていることから, 粒子同士 の接触点には接触熱抵抗が生じているものと推測され る. $\lambda_{e} / \lambda_{s}$ の $\phi$ に対する增加割合は, $0.68<\phi<0.8$ で 一旦小さくなるが, $\phi>0.8$ では再び大きくなる. 前 述の図 8 に示した $\sum L_{c} / \sum L_{p}$ の変化傾向と比較する と, $\sum L_{c} / \sum L_{p}$ の変化が小さい低 $\phi$ 領域と高 $\phi$ 領域で, $\lambda_{e} / \lambda_{s}$ の変化が顕著となっている. 寸なわち, 充填率の 増加に比べて見かけの接触面積の増大が小さい場合に は, 真の接触面積が増大していると考えられ, 接触熱抵 抗が减少により有効熱伝導率が増大寸るものと考えら れる.

一方, 同図において, $\phi$ を一定として $P_{a}$ の影響につ

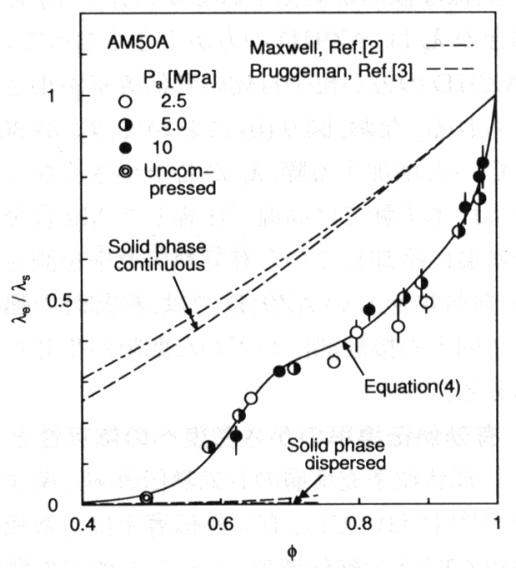

(a) AM50A

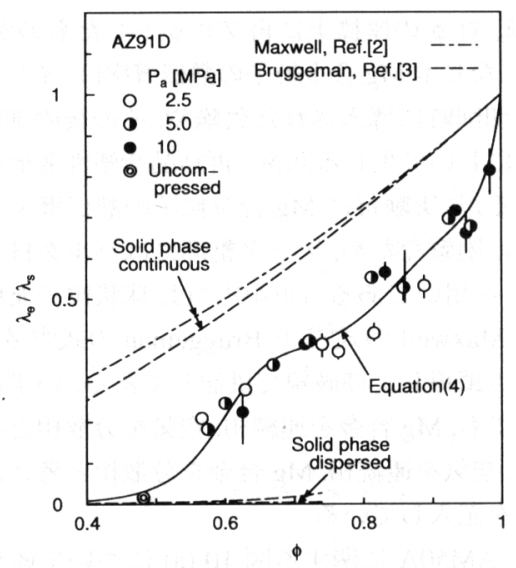

(b) AZ91D

Fig. 10 Variation of effective thermal conductivity ratio with bulk density ratio.
いて観察すると, $\lambda_{e} / \lambda_{s}$ は $P_{a}$ の低下に伴い小さくなる 傾向にあるが, 全体的には $P_{a}$ の影響は小さいと言え よう.

次いで, AZ91D に関する図 10 (b) について観察す ると, 定性的な傾向は図 10 (a) の AM50A の場合と同 様であるが, $\lambda_{e} / \lambda_{s}$ の実験值は, 低 $\phi$ 領域で AZ91D の 方が大きく, 両者の比は $\phi$ の増加に伴い減少している. 従来の式による予測值に顕著な差が見られないことか ら, 材料の違いにより接触状態に差が生じたことなど が原因と考えられる.

以上に述べたように, $\mathrm{Mg}$ 合金粒子充填層の有効熱 伝導率は, 充填状態や粒子同士の接触状態に大きく影 響される. 見かけの接触面積については, 図 8 の結果 を得ているが, 接触熱抵抗に大きく影響する真実接触 面積など接触部の詳細は不明であり, 現段階では正確 な熱流モデルの構築は難しい. しかし冒頭でも述べた ように, Mg 合金射出成形機の性能予測シミュレーショ ンの構築が急務であることから，以下に述べる簡易モ デルを用いて有効熱伝導率の定式化を試みた.

粒子充填層の有効熱伝導率は, 図 11 の左図のよう に, 直列 ·並列モデルで表される場合が多い.(1)このモ デルにおいては, 固体部を流れる熱は, 固体のみを伝わ る熱と薄い流体層を介して伝わる熱とに分けられるが, 本研究では, 図 11 の右図に示すように, 固体同士の接 触部に接触熱抵抗を導入し, 簡略化を図った. 本モデル による有効熱伝導率は, 次式のようになる.

$$
\frac{\lambda_{e}}{\lambda_{s}}=\frac{\phi}{1+f}+(1-\phi) \frac{\lambda_{f}}{\lambda_{s}}
$$

ここに, $f=R A \lambda_{s} / \ell, R$ は接触熱抵抗, $A$ は接触面積, $\ell$ は熱流方向の接触点間距離である. $A, \ell$ は粒子寸法と 充填状態に影響され, $R$ はこれらに加えて流体の熱伝 導率にも影響を受けると考えられる. 本研究では, 粒子 寸法や流体の熱伝導率を変化させていないことから, $f$ を充填率 $\phi$ のみの関数 $f(\phi)$ と考えた. また, $\phi=1$ で

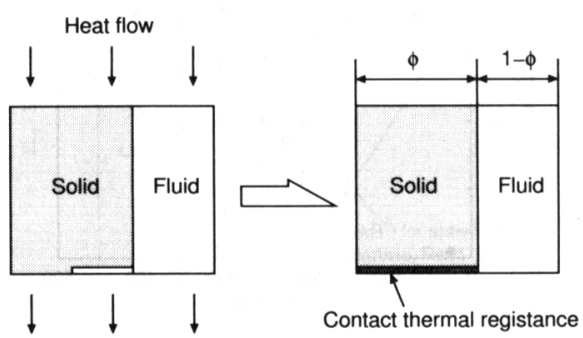

Fig. 11 Series-parallel model and simplified model. 
$\lambda_{e} / \lambda_{s}=1$ となるよう,

$$
f(\phi)=\sum_{i=1}^{5} C_{i}(1-\phi)^{i}
$$

とし,未定係数 $C_{i}$ を最小二乗法により決定したところ, 以下の結果を得た.

\section{AM50A}

$$
\left.\begin{array}{ll}
C_{1}=11.6, & C_{2}=-93.9 \\
C_{3}=6.37 \times 10^{2}, & C_{4}=-2.38 \times 10^{3} \\
C_{5}=3.30 \times 10^{3} &
\end{array}\right\}
$$

AZ91D

$$
\left.\begin{array}{ll}
C_{1}=14.3, & C_{2}=-2.13 \times 10^{2} \\
C_{3}=1.57 \times 10^{3}, & C_{4}=-5.06 \times 10^{3} \\
C_{5}=5.88 \times 10^{3} &
\end{array}\right\}
$$

式 (4)による予測值を $\lambda_{e c}$ とし, $\left(\lambda_{e c} / \lambda_{e}-1\right)$ の標準 偏差を求めたところ, AM50A では 17.7\%, AZ91D で は $26.1 \%$ であった. なお, 式 (4)では, 有効熱伝導率 $\lambda_{e}$ が充填率 $\phi$ の関数として表現されているため, 温度, 圧 力, 時間加有効熱伝導率 $\lambda_{e}$ を求めるには, これらの 因子と充填率の関係を表す前報(2) の実験整理式を併 用する必要がある.

\section{5. 結}

\section{言}

AM50A およびAZ91D の直方体状粒子を高温で圧 縮して作製した $\mathrm{Mg}$ 合金粒子充填層の有効熱伝導率を 測定し,以下の結論を得た.

(1) $\mathrm{Mg}$ 合金粒子充填層を作製するときの温度および 圧力が高いほど, また, $\mathrm{Mg}$ 合金粒子の熱伝導率が 大きいほど, $\mathrm{Mg}$ 合金粒子充填層の有効熱伝導率 は大きくなる.

（2）粒子の材質を一定とした場合には, $\mathrm{Mg}$ 合金粒子 充填層の有効熱伝導率は, 主として $\mathrm{Mg}$ 合金の充 填率により支配され，充填率の増加に伴い大きく なる. また, 有効熱伝導率の充填率への依存性は, 充填率が低い領域と高い領域で顕著となる.

(3) $\mathrm{Mg}$ 合金粒子充填層の有効熱伝導率に関する式 (4) を得た.

今後の課題は, $\mathrm{Mg}$ 合金粒子充填層の有効熱伝導率 に与える周囲流体の影響や, 粒子寸法の影響を検討す ることである. また，本報および前報(2) の結果に基づ き, $\mathrm{Mg}$ 合金射出成形機における $\mathrm{Mg}$ 合金粒子群の輸 送·融解プロセスの数值シミュレーションモデルを構 筑することも重要な課題である.
謝辞

最後に, 本研究の一部は文部科学省科学研究費補助 金若手研究 (B) 課題番号 15760137 の補助によること を記して感謝の意を表す。

\section{文献}

(1) Japan Society of Thermophysical Properties, Handbook of Thermophysical Properties, (1990), 176, Yokendo.

(2) Ozaki, K. et al., Transactions of the Japan Society of Mechanical Engineers, Series A, to be published.

(3) Maxwell, J. C., A Treatise on Electricity and Magnetism, 3rd ed., (1904), 465, Oxford Univ. Press.

(4) Bruggeman, D.A.G., Annalen der Physik., 24-5 (1935), 636.

(5) Data Sheet Die Cast Magnesium Alloys, Hydro Magnesium, (1996).

(6) Mordike, B. L. and Kainer, K. U., Magnesium Alloys and their Applications, (1998), 41, WerkstoffInformationsgesellschaft.

(7) The Japan Society of Mechanical Engineers ed., JSME Date Handbook: Heat Transfer 4th Edition, (1986), 320, The Japan Society of Mechanical Engineers.

(8) p.318 of Ref.(7)

(9) p.347 of Ref.(7)

(10) Kamado, S. et al., Advanced Manufacturing Technologies of Magnesium Alloys, (2005), 28, CMC Publishing.

(11) Fishmeister, H. F. and Arzt, E., Powder Metall, 26 (1983), 179. 